\title{
Upgrading technological processes of operating the railway infrastructure facilities
}

\author{
Vladimir Apattsev ${ }^{1}$, Vladimir Aksenov ${ }^{1}$, and Anton Zavyalov ${ }^{1, *}$ \\ ${ }^{1}$ Moscow State University of Railway Engineering (MIIT), Chasovaya 22/2, Moscow, 125315 Russia
}

\begin{abstract}
The analysis of incidents in rail transport shows that the main reason for this is erroneous human actions. In the system "a person - a technical system - a production environment" a person is the "weakest link", determining the reliability and safety of the system functioning. Most incidents on the railway infrastructure occur at the stage of its facilities operation because of relevant technological processes poor-quality implementation. The article presents a method for upgrading technological processes of railway infrastructure facilities operation, the implementation of which allows to identify the most critical technological processes and to reduce the influence of the human factor, thereby increasing the reliability and safety of the transportation process.
\end{abstract}

\section{Introduction}

The ensuring effectiveness of the technological processes quality (TP) requires constant evaluation of factors affecting compliance with the requirements for the system, as well as control and inspection of the technological processes that are usually implemented within the quality management system (QMS) [1, 2].

There are many methods of quality management $[3,4,5,6]$, but not all are applicable to the management of technological processes quality. Risk management as one of the QMS processes allows to effectively reduce the influence of the human factor [7] in the design and implementation of technological processes through targeted preventive and corrective actions that minimize the influence of possible deviations in the process of the human machine system.

The most important stage in risk management is their evaluation. Currently, many risk assessment methods have been developed and applied, which are complicated, the uncertainty degree of the data and information to be processed, and the amount of resources necessary for the implementation. Table 1 provides a comparative analysis of risk assessment methods.

\section{Research methods}

One widely used technique is Failure Mode and Effects Analysis (FMEA), which forms the basis of the standard in the automotive industry [8]. The method allows to identify potential

*Corresponding author: zavant@mail.ru 
inconsistencies in technological processes, their causes and consequences, assess the risks of their occurrence and not detection, in order to take measures to eliminate or reduce the probability and damage from their occurrence.

Table 1. Comparative analysis of risk assessment methods.

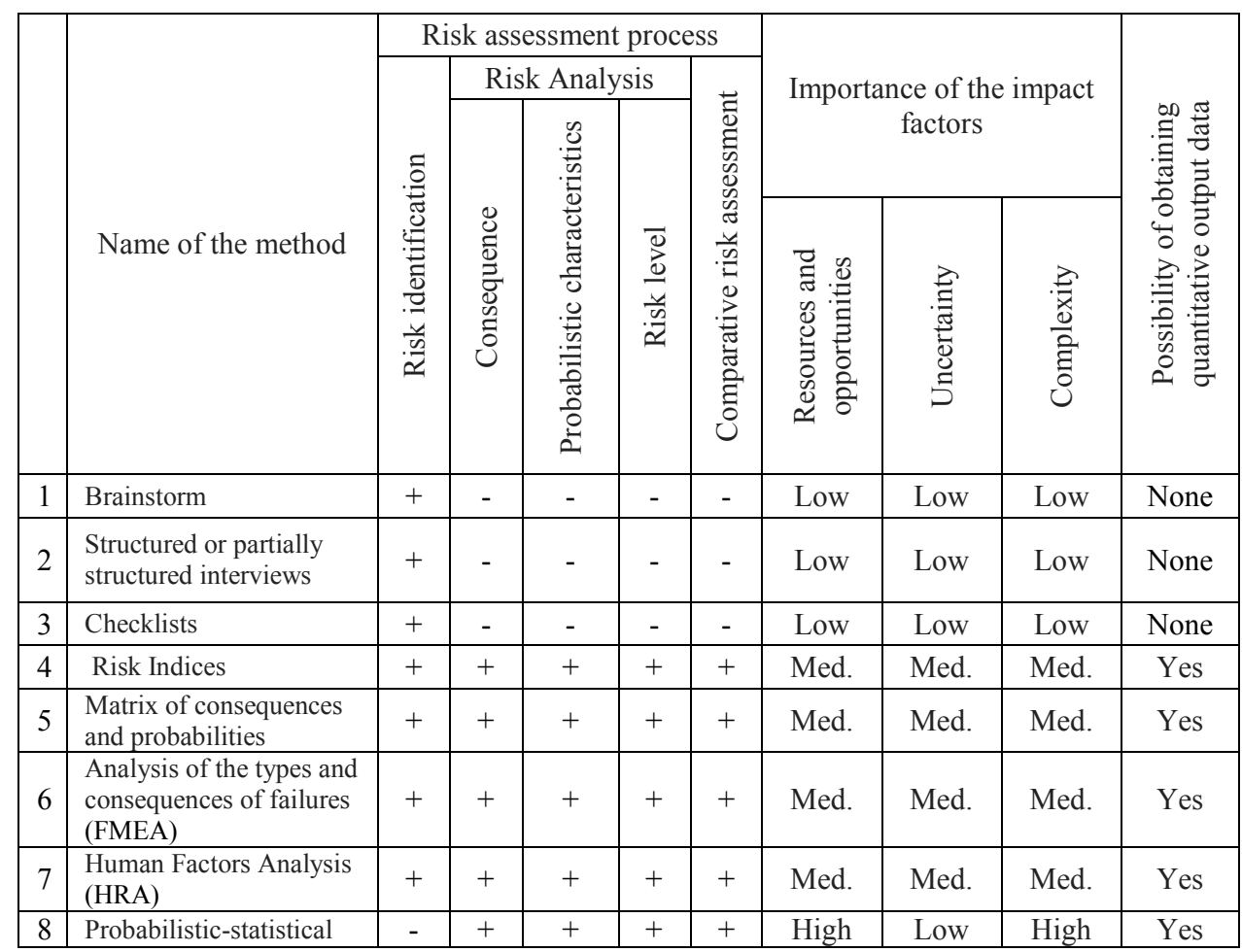

The method is applicable both to the new technological process at the stage of its design, allowing to prevent the introduction of insufficiently developed processes into production, and at the implementation stage when updating the processes, for example, in connection with the modernization of the technical devices or equipment used.

The essence of the method consists in the expert evaluationof potential nonconformities possible types by a specially created working group on three criteria:

- significance, measured in terms of the severity of the consequences of this discrepancy

(S);

- relative frequency (probability) of occurrence $(\mathrm{O})$;

- the relative frequency (probability) of detection of this discrepancy or its cause (D).

For each of these criteria there is a scale of expert assessments in the range from 1 to 10. Moreover, the higher the significance or frequency of non-compliance occurrence, the higher the corresponding estimate.

After receiving expert assessments $\mathrm{S}, \mathrm{O}, \mathrm{D}$, the priority risk number $(\mathrm{PRN})$ is calculated according to the formula:

$$
P R N=S \cdot O \cdot D
$$

The PRN is compared with its adopted limit value and, in case of exceeding, corrective measures are implemented aimed at finalizing the analyzed process.

To improve the effectiveness of the proposed method in assessing the impact of human factors, we recommend that it be supplemented with the Human Reliability Assessment 
(HRA) method [9], which identifies possible employee errors and their causes, and qualitatively and quantitatively assesses the risk of identified errors.

Consolidation of the above methods, as well as the generalized structural method of functional networks Gubinsky AI. [10] allowed to develop effective solutions for identifying and assessing technological risks, providing the possibility of the human factor influence reducing at the design and implementation stages of technological processes.

At the first stage, an expert-statistical analysis method is used to identify the most critical technological processes. Namely, based on the existing statistical data, the frequency of various incidents (failures, faults) detected during theoperation of infrastructure facilities is determined, after which the inconsistencies are ranked by frequency. Then the expert establishes a connection between the types of incidents and the technological processes of operating the infrastructure facilities. Thus, the most critical technological processes are determined. It is possible to complicate the task to be solved by adding another indicator, namely the assessment of the potential damage from each incident. The combination of incidents and potential damage frequency will reveal the riskiest technological processes.

At the second stage, the most critical or risky technological processes are formalized and decomposed in the form of a functional network.

Further, if it is necessary to solve the task of optimizing the technological process, the corresponding parameters of the technological operations are determined.

At the fourth stage, potential inconsistencies, undesirable consequences, causes or mechanisms of non-compliance and detection measures are identified for each operation of the process in question.

The fifth stage determines the frequency (probability) of occurrence $\mathrm{O}$ and the detection of $\mathrm{D}$ discrepancies, as well as the severity of the consequences of $\mathrm{S}$, to which the discrepancy can result. After that, according to formula (1), the priority number of risk is calculated.

Figure 1 presents an algorithm for implementing the proposed solutions to reduce the influence of the human factor at the design and implementation stages of technological processes.

\section{Results of the study}

Consider the application of the proposed solutions for identifying and assessing risks in the process of laying the switch gear on reinforced concrete beams with two EBC 300/5 cranes with deep ballast cleaning by the RM-80 machine.

To determine potential inconsistencies, which must be eliminated as a matter of priority (the riskiest), an operational analysis of the process using FMEA analysis was performed.

After a detailed study of the analysis, ten operations were identified in the process under consideration (Table 2), which have a greater impact on the outcome of the entire process.

For all potential discrepancies that have a PRN value $\geq$ PRN gr (as a rule, 100 points), recommendations were proposed aimed at reducing the risk to an acceptable level by reducing the value of the " $\mathrm{D}$ " factor - primarily using modern monitoring and diagnostic methods. 


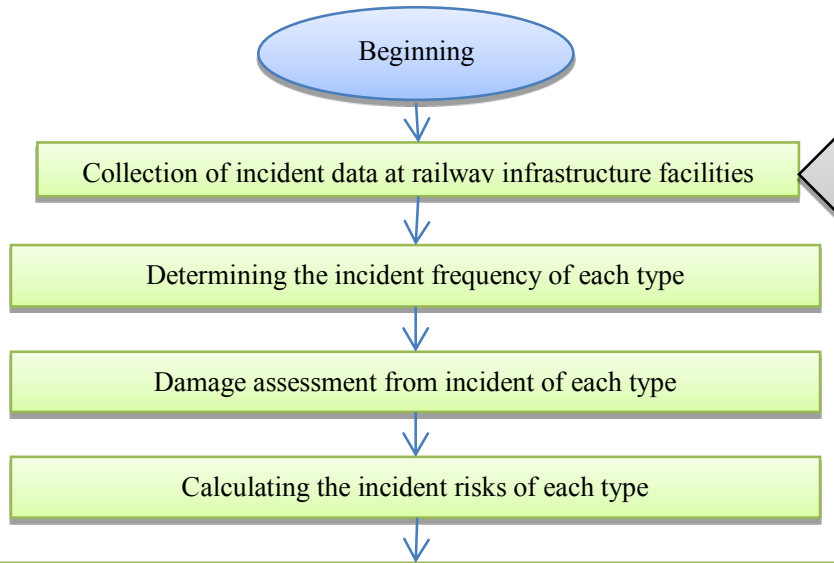

Comparison of incidents with technological processes (TP) of infrastructure facilities operation
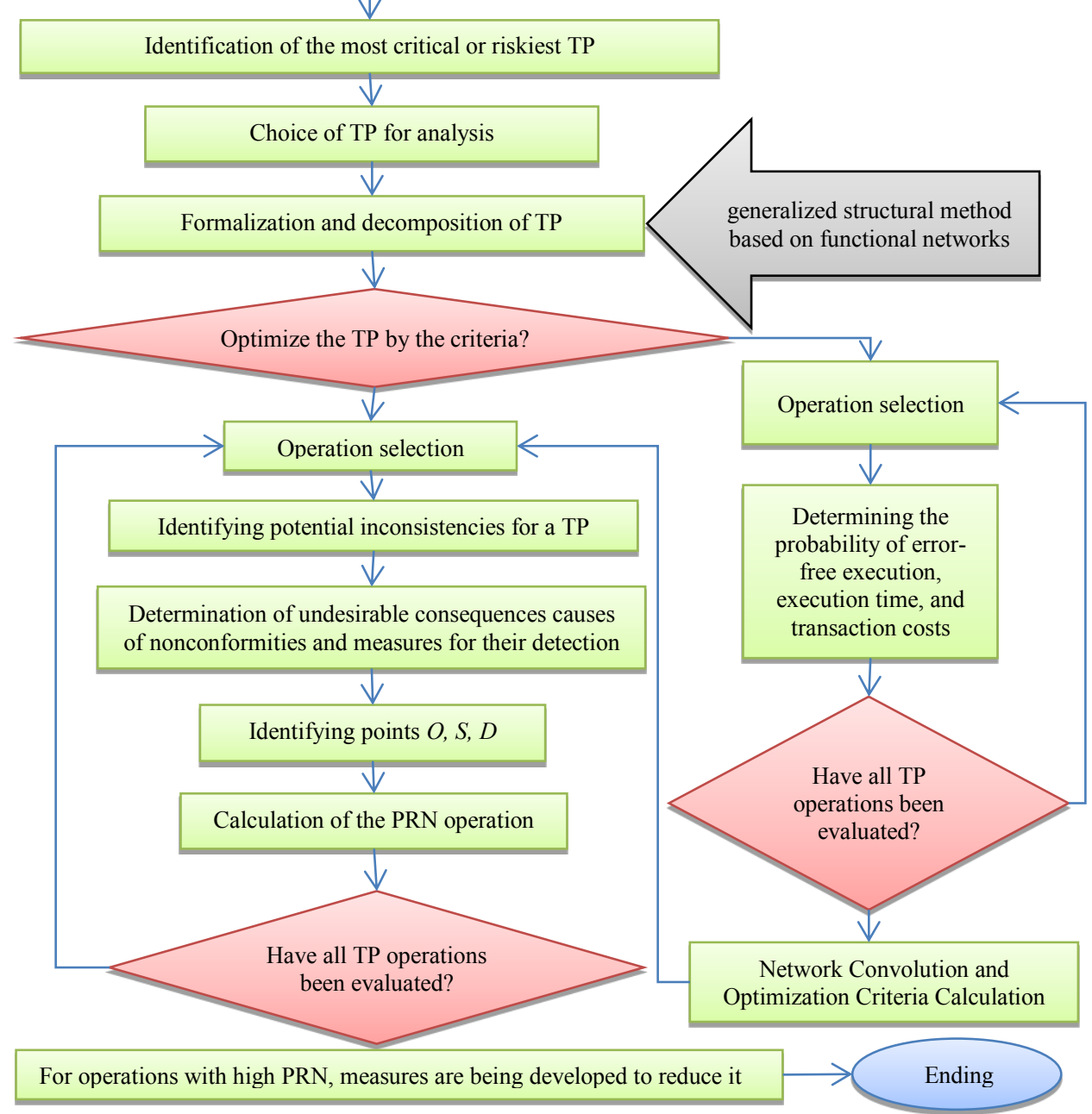

Fig. 1. Algorithm for identification and assessment of technological risks at the stages of design and implementation of TP. 
Our analysis of the switch operation technological processes at two large sorting stations in the Moscow region: Bekasovo-Sortirovochnoe and Orekhovo-Zuyevo, using an automated system for keeping commission records of monthly inspections of the station (AS KMO) showed that a significant proportion of the detected malfunctions (Figures 2,3), is associated only with two of the one hundred and twelve operational technological processes of operation: TNK No. 137 "Removing the lateral rolling (burrs) from rails and metal parts of the boom "and TNK No. 162" Adjusting the track width on a turnout using a clamping device ". Further decomposition of these technological processes revealed several specific operations with exceeding the maximum permissible value of the PRN, which require adjustment. It should be noted that almost all the identified inconsistencies are related to the human factor.

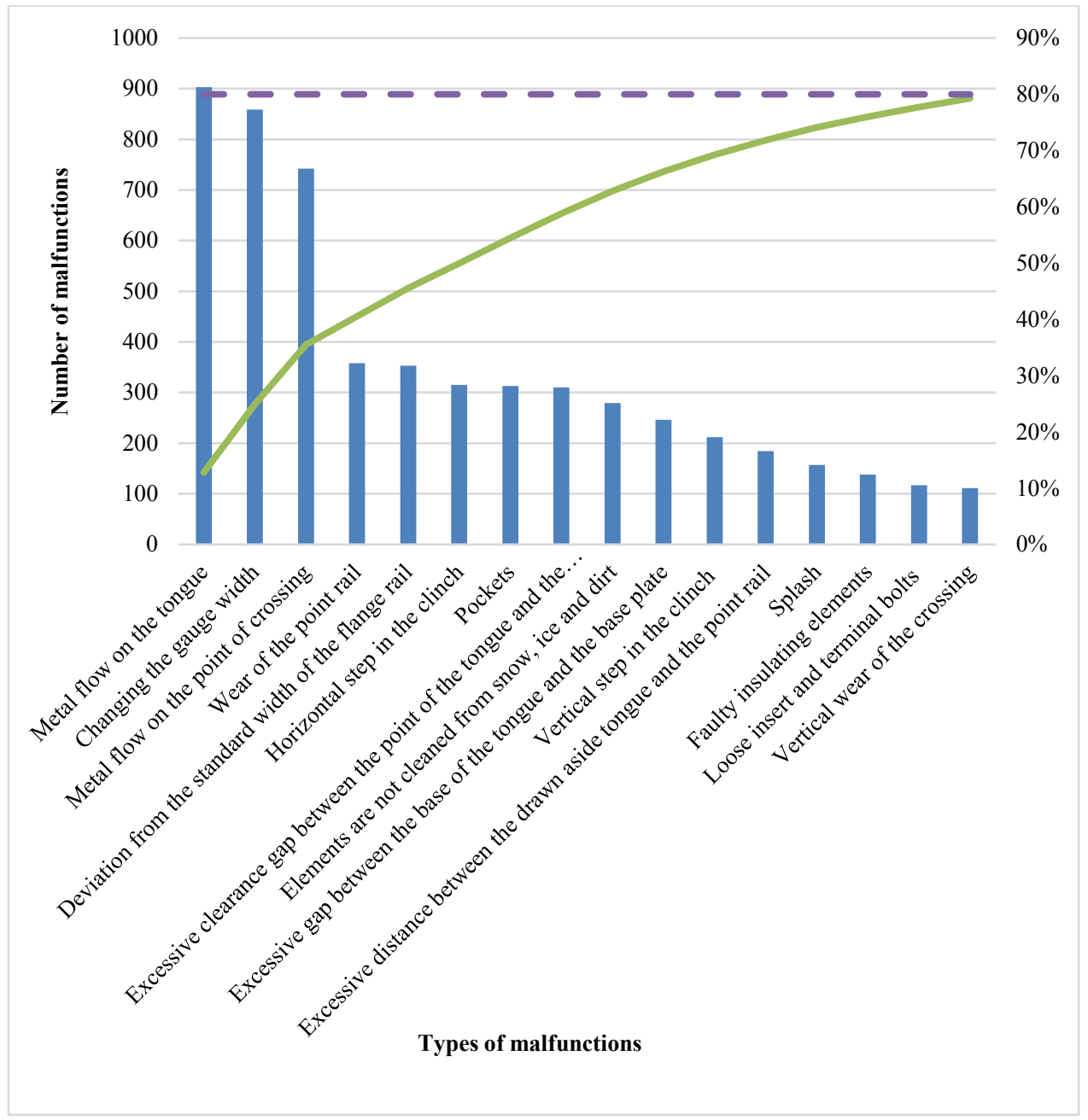

Fig. 2. Distribution of defect switches at the station Bekasovo-Sortirovochnoe. 


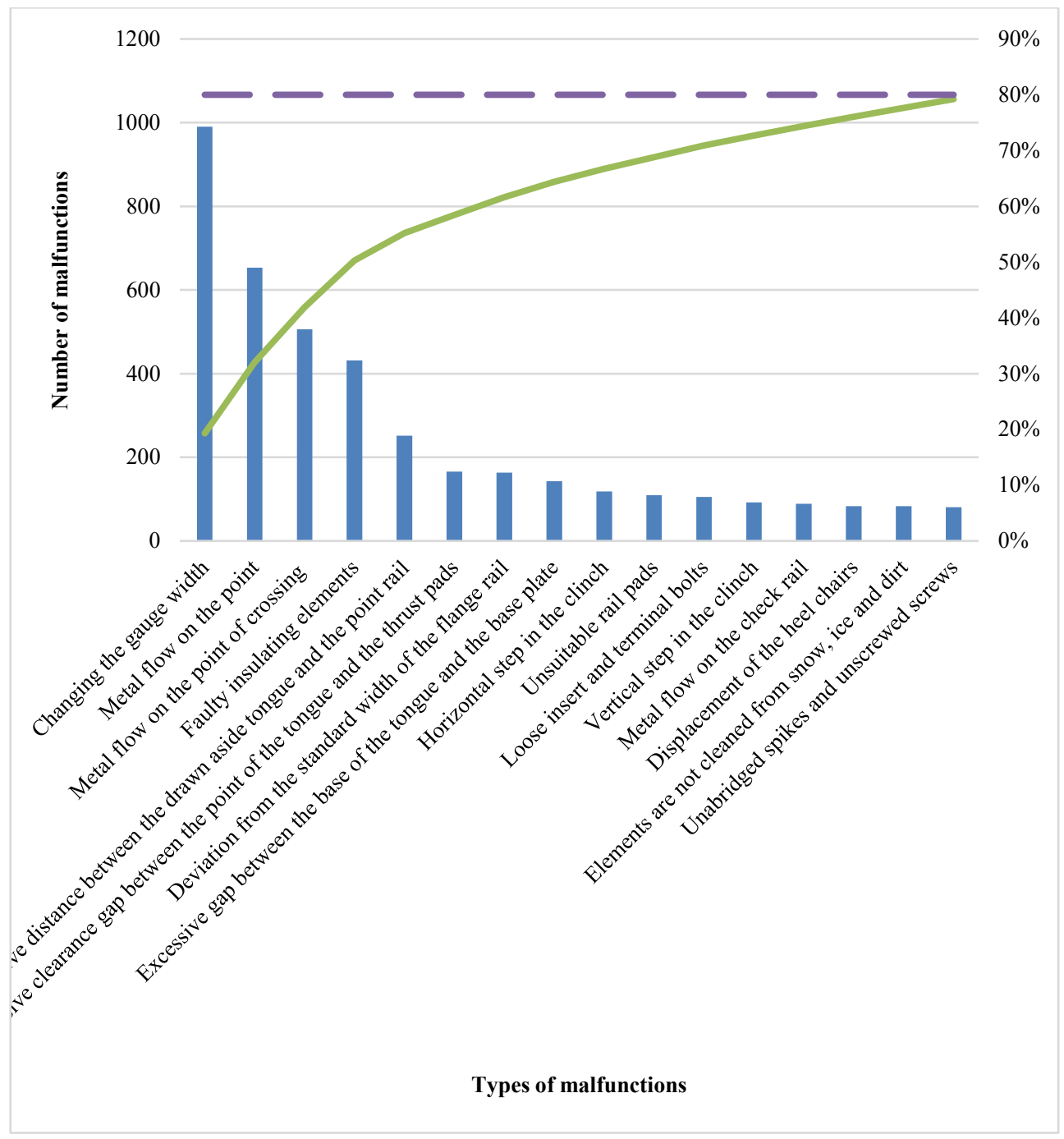

Fig. 3. Distribution of defect switches at the station Orekhovo-Zuevo. 
Table 2. Technological process analysis results of laying the turnout on reinforced concrete beams with two EBC 300/5 cranes with deep ballast cleaning by the RM-80 machine.

\begin{tabular}{|c|c|c|c|c|c|c|c|c|c|c|}
\hline \multirow{2}{*}{$N$} & \multicolumn{3}{|c|}{$\begin{array}{l}\text { Installation of switch gear on reinforced concrete beams with } \\
\text { two cranes EBC-300/5 with deep ballast cleaning by RM-S0 } \\
\text { machine }\end{array}$} & \multicolumn{7}{|c|}{ Result of analysis } \\
\hline & Stage TP & $\begin{array}{c}\text { Transformations of } \\
\text { the TP }\end{array}$ & $\begin{array}{c}\text { Reasons for the } \\
\text { violation of the TP }\end{array}$ & $\begin{array}{l}\text { Consequences of } \\
\text { the TP violation }\end{array}$ & $\mathrm{S}$ & $\mathrm{O}$ & D & PRN & \begin{tabular}{|c|} 
Violation \\
$\begin{array}{c}\text { identification } \\
\text { method }\end{array}$ \\
\end{tabular} & Corrective measures \\
\hline 1 & $\begin{array}{l}\text { Checking the gauge } \\
\text { width according to the } \\
\text { template }\end{array}$ & $\begin{array}{c}\text { Absence of leaders } \\
\text { and measuring } \\
\text { templates }\end{array}$ & $\begin{array}{l}\text { Unavailability for } \\
\text { the work }\end{array}$ & $\begin{array}{l}\text { Impossible to } \\
\text { open the traffic }\end{array}$ & 10 & 6 & 3 & 180 & Diagnostics & $\begin{array}{l}\text { The use for control of } \\
\text { measuring trolleys } \\
\text { switchgear with the travel } \\
\text { data logging }\end{array}$ \\
\hline 2 & $\begin{array}{l}\text { The turnout closing } \\
\text { execution with the } \\
\text { arrival of the cranes } \\
\text { EBC-300/5 andthe } \\
\text { switch translation }\end{array}$ & $\begin{array}{c}\text { No order to produce } \\
\text { works }\end{array}$ & $\begin{array}{l}\text { Failure to comply } \\
\text { with the procedure } \\
\text { for providing } \\
\text { "windows" }\end{array}$ & $\begin{array}{l}\text { Canceling the } \\
\text { work }\end{array}$ & 9 & 6 & 3 & 162 & Monitoring & $\begin{array}{l}\text { The introduction of } \\
\text { automated control systems } \\
\text { to monitor the preparation } \\
\text { for work in the " windows" }\end{array}$ \\
\hline 3 & $\begin{array}{l}\text { Voltage removal and } \\
\text { grounding of the } \\
\text { contact network }\end{array}$ & $\begin{array}{l}\text { Lack of order to } \\
\text { produce works }\end{array}$ & $\begin{array}{l}\text { Failure to comply } \\
\text { with the "windows" } \\
\text { provision procedure }\end{array}$ & $\begin{array}{l}\text { Canceling the } \\
\text { work }\end{array}$ & 9 & 6 & 3 & 162 & Monitoring & $\begin{array}{c}\text { Monitoring Implementation } \\
\text { of ground contact } \\
\text { monitoring devices on the } \\
\text { traction substations with } \\
\text { data transmission to the } \\
\text { energy dispatcher }\end{array}$ \\
\hline 4 & $\begin{array}{c}\text { Pulling up the nuts of } \\
\text { the butt joints }\end{array}$ & $\begin{array}{c}\text { Reducing the force } \\
\text { of twisting }\end{array}$ & $\begin{array}{l}\text { The holding force } \\
\text { weakening of the } \\
\text { butt-end linings }\end{array}$ & $\begin{array}{l}\text { Restriction of } \\
\text { the speed or } \\
\text { closed traffic }\end{array}$ & 8 & 6 & 3 & 144 & Visual & $\begin{array}{l}\text { Visual Introduction of } \\
\text { electronic torque wrenches } \\
\text { with the function of data } \\
\text { saving and the method of } \\
\text { measurements video } \\
\text { recording }\end{array}$ \\
\hline 5 & $\begin{array}{l}\text { Installation and } \\
\text { adjustment of the } \\
\text { contact network }\end{array}$ & $\begin{array}{l}\text { Absence of a } \\
\text { contact network }\end{array}$ & $\begin{array}{l}\text { The absence of } \\
\text { workers or tools } \\
\text { and adaptations }\end{array}$ & $\begin{array}{c}\text { The } \\
\text { impossibility of } \\
\text { using electric } \\
\text { traction }\end{array}$ & $\mathrm{S}$ & 4 & 4 & 128 & Visual & $\begin{array}{l}\text { Implementation of step-by- } \\
\text { step monitoring method with } \\
\text { video results fixing and } \\
\text { transmission to the } \\
\text { dispatching device }\end{array}$ \\
\hline 7 & $\begin{array}{c}\text { Preparation of a place } \\
\text { for charging the } \\
\text { chipper PM-S0 }\end{array}$ & $\begin{array}{c}\text { No ready space for } \\
\text { charging }\end{array}$ & $\begin{array}{l}\text { Unavailability for } \\
\text { work }\end{array}$ & $\begin{array}{l}\text { Increased work } \\
\text { time }\end{array}$ & 9 & 6 & 2 & 108 & Visual & $\begin{array}{l}\text { Visual Implementation of } \\
\text { methods for photo fixing the } \\
\text { performed work results with } \\
\text { data transmission to the } \\
\text { dispatching device }\end{array}$ \\
\hline 8 & $\begin{array}{c}\text { Adjustment of control } \\
\text { tracts by risks }\end{array}$ & $\begin{array}{c}\text { Pressing of wits } \\
\text { with false readings }\end{array}$ & $\begin{array}{l}\text { Dynamic loads } \\
\text { from rolling stock }\end{array}$ & $\begin{array}{c}\text { Switch control } \\
\text { loss gear under } \\
\text { the rolling stock }\end{array}$ & 7 & 5 & 3 & 105 & Visual & $\begin{array}{l}\text { Photographic fixation } \\
\text { methods of the performed } \\
\text { work results with data } \\
\text { transmission to dispatching } \\
\text { equipment }\end{array}$ \\
\hline 9 & Installation of twists & $\begin{array}{l}\text { Nut weakening due } \\
\text { to dynamic loads }\end{array}$ & $\begin{array}{l}\text { Dynamic loads } \\
\text { from the rolling } \\
\text { stock }\end{array}$ & $\begin{array}{l}\text { Loss of control } \\
\text { of the switch } \\
\text { gear under the } \\
\text { rolling stock }\end{array}$ & 7 & 5 & 3 & 105 & Visual & $\begin{array}{l}\text { Photographic fixation } \\
\text { methods of the performed } \\
\text { work results with the } \\
\text { transfer of data to the } \\
\text { dispatching device }\end{array}$ \\
\hline 10 & $\begin{array}{l}\text { Removing the earthing } \\
\text { rods and applying } \\
\text { voltage to the mains } \\
\text { supply }\end{array}$ & $\begin{array}{l}\text { Voltage supply in } \\
\text { the presence of } \\
\text { grounding rods }\end{array}$ & $\begin{array}{l}\text { False report to the } \\
\text { energy manager } \\
\text { about the readiness } \\
\text { for voltage supply }\end{array}$ & $\begin{array}{c}\text { Failure of the } \\
\text { contact network } \\
\text { devices }\end{array}$ & 10 & 2 & 5 & 100 & Monitoring & $\begin{array}{l}\text { The introduction of earthing } \\
\text { devices for the contact set in } \\
\text { traction substations with the } \\
\text { transmission of telemetry } \\
\text { data to the energy dispatcher }\end{array}$ \\
\hline
\end{tabular}

\section{The discussion of the results}

The developed solutions are most effective for newly created or processed technological processes, since they allow not only to analyze the proposed technological process for potential discrepancies, but also to evaluate its efficiency, quality and reliability indicators based on the generalized structural method of functional networks of A.I. Gubinskiy. 
To effectively implement the proposed solutions, it is necessary to refine the existing automated systems in Russian Railways, linking the incidents recorded (trauma and micro tracking of the employee, technological and traffic safety violations, failures of technical devices, etc.) to specific operations of the technological processes being implemented. The collected statistics will allow to identify high-risk operations and, therefore, the most critical technological processes, which require the fastest actualization.

\section{References}

1. V.I. Apattsev, Science and technology of transport 3, 44-47 (2013)

2. V.A. Aksenov, A.V. Gorelik, A.M. Zavyalov, Science and technology of transport 1, 7073 (2013)

3. A.M. Zavyalov, P.A. Nevarov, Science and technology of transport 2, 98-105 (2015)

4. V.V. Efimov, Statistical methods of quality management (UISTU, Ulyanovsk 2003)

5. V.V. Shusherin, S.V. Kortov, A.S. Zetkin, Means and methods of quality management: a textbook (GOU VPO USTU, Ekaterinburg, 2006)

6. M.M. Kane, B.V. Ivanov, V.N. Koreshkov, A.G. Skhirtladze, Systems, methods and tools of quality management: a textbook (Peter, $\mathrm{SPb}, 2008)$

7. A. Zavyalov, V. Aksenov, E. Volkova, A. Solodkov, A. Baskakov, Young Researchers in Electrical and Electronic Engineering (EIConRus), 2018 IEEE Conference of Russian, 1964-1968, DOI: 10.1109/EIConRus.2018.8317495.

8. Russian Federation Standard GOST R 51814.2-2001

9. J. Bell, J. Holroyd, Review of human reliability assessment methods (HSE Books, Buxton, 2009)

10. A.N. Adamenko, A.T. Asherov, I.L. Berdnikov, P.I. Paderno, Information-controlling man-machine systems: Research, design, testing: directory (Mechanical Engineering, Moscow, 1993) 